\title{
Yerel Politikaların Şekillenmesinde Dijital Demokrasi Uygulaması Olarak Antalya Muratpaşa Belediyesi Komşu Meclisi
}

\author{
Digital Democracy in Shaping Local Policies: Antalya Muratpaşa Municipality Neighboring Assembly
}

\author{
Oğuzhan ERDOĞAN \\ Dr. Öğr. Üyesi, Bucak Belediye Başkan Yardımcısı, \\ Burdur Mehmet Akif Ersoy Üniversitesi, \\ Bucak Hikmet Tolunay MYO, \\ oerdogan@mehmetakif.edu.tr \\ https://orcid.org/0000-0003-3809-6688
}

Makale Başvuru Tarihi: 12.04.2020

Makale Kabul Tarihi: 26.04.2020

Makale Türü: Araştırma Makalesi

Anahtar
Kelimeler:

Yerel Yönetimler,

Yerel Politika,

Yerel Demokrasi,

Katılım,

\section{ÖZET}

İnsanlı tarihi büyük bir değişim ve dönüşüm dönemine tanıklık etmektedir. Yaşamın her alanında dijital teknolojilerin, yapay zekânın, yazılım dilinin yarattı̆̆ değişim hissedilmektedir. Özellikle demokratik yönetim anlayışın temsil eden ve toplum için hizmet üreten kurumların bu değişimin dışında kalması düşünülemez. Vatandaşa en yakın hizmet veren kuruluş olan ve demokrasilerin ayrılmaz bir parçası konumundaki yerel yönetimler de yaşanan bu değişimi daha güçlü, daha katılımcı, biz duygusunu geliştiren, ortak yaşamı kolaylaştıran demokratik bir yaşam için firsat olarak değerlendirmektedir. Antalya Muratpaşa Belediyesi tarafindan Türkiye'nin ilk dijital demokrasi platformu olarak lanse edilen “Komşu Meclisi” uygulaması da mümkün olan en yüksek teknolojiyi kullanarak, daha katılımcı bir kent yönetimini, vatandaşların en üst düzeyde kendini ait hissedebileceği bir kamusal alan ve kamusal birlikteliği ve yerel yönetimlere güveni amaç edinen bir platform olarak kurgulanmıştır. Çalıșmada ilk olarak yerel yönetimler kavramı ele alınmış, daha sonra yerel yönetimlerin aldĭ̆ı kararlar bütünü olarak da tanımlanan yerel politika kavramına değinilmiş, yerel politikanın uygulama alanlarından biri olan yerel demokrasi ve Türkiye'de yerel demokrasi konuları irdelenmiştir. Son olarak da Antalya Muratpaşa Belediyesinden alınan veriler ve bilgiler ışığında Türkiye'nin ilk dijital demokrasi platformu olarak tanıtılan "Komşu Meclisi" uygulaması tüm hatlartyla incelenerek, değerlendirilmiştir.

\begin{abstract}
Human history is witnessing a period of great change and transformation. The change created by digital technologies, artificial intelligence and software language is felt in every area of life. Especially the institutions representing democratic management understanding and producing services for society cannot be excluded from this change. Local governments, which are the closest service to citizens and are an integral part of democracies, consider this change as an opportunity for a stronger, more participatory, democratic life that enhances our sense of emotion and facilitates common life. The Neighbor Assembly" which is touted by Antalya Muratpaşa Municipality as the Turkey's first digital democracy platform, founded as a platform that aiming to create a public space where the citizens feel themselves highly belonged and to provide an atmosphere of trust where they can solve the problems eachother. Firstly, the concept of local government was discussed in the study, then the local democracy which is one of the implementation field of local policies and local democracy in Turkey issues were examined. Finally, in the light of the received data from Muratpaşa Municipality, the implementation of "The Neighbor Assembly" which is touted as Turkey's first digital democracy platform was evaluated in details.
\end{abstract}




\section{GIRISS}

Toplum dinamik bir yapıdır. Bunun en önemli göstergelerinden biri sosyal, siyasal, yönetsel, hukuksal, kültürel, teknolojik ve ekonomik alanda dünya genelinde meydana gelen gelişmeler sonucu geleneksel yönetim anlayışının değişmesidir. Doğal olarak devletlerin, hükümetlerin karar alma/verme süreci de bu değişimden etkilenmektedir. Karar alma gücünü elinde bulunduran hükümetin kamu kurum ve kuruluşları aracıllğıyla yapmış olduğu eylem ve işlemler bütünü ya da sorunlar, ihtiyaçlar ve imkânlar karşısında takındığı tavır ve uygulama olan kamu politikası, topluma yön veren önemli bir kamu yönetimi elemanı olarak karşımıza çıkmaktadır. Hiç kuşkusuz vatandaşlara yerel kamu hizmeti sunan en yakın birim olan yerel yönetimler, kamu politikalarının yerelde uygulandığı alanlardır. Günümüzde hızlı kentleşme ve göçlerle birlikte yeniden formüle edilen yerel yönetimlerin vatandaşların değişen ihtiyaçlarını karşılamak, sorunlarına çözüm bulmak ve onları politika yapım sürecine katmak için güçlü iradesi mevcuttur. İşte tam da bu noktada merkezine kent ve kent yönetimini alan, kent ölçeğinde faaliyet gösteren kişi, kurum ve kuruluşların, kentin ve kent sakinlerinin sorunlarını ele alan, yerel kaynakları kullanarak vatandaşların mutluluğunu, refahını ve adaletini sağlamak üzere, yerel yönetimler üzerinden yerel toplumu idare etme sanatı olarak yerel politika önemli bir araç olarak karşımıza çıkmaktadır (Akdoğan, 2009:1). Yerel politika yerel ölçekte yapılan politikalar bütünüdür.

Yerel yönetimlerin tarihsel gelişimi değerlendirildiğinde, yerel halkın kendi kendini yönetmesinin bir pratiği olarak tanımlanan yerel demokrasi günümüzde vatandaşların yerel politika yapım sürecine geniş tabanlı katılımında önemli bir rol oynamaktadır. Nitekim yerel yönetimler, ülkede demokrasinin yerleşmesi ve gelişmesi bakımından değerlidir. Çünkü yerelde demokrasi olmadan ulusal düzeyde bir demokrasinin olması da düşünülemez. Yerel siyasetin önemli aktörlerinden biri olan ve demokrasinin okulu olarak görülen yerel yönetimler, ülke genelinde siyasal katılımın artmasında ve vatandaşlar arasında demokrasi bilincinin geliştirilmesinde belirleyici konumdadır. Bu yüzden dünya genelinde farklı yerel yönetim birimleri tarafindan vatandaşların politik karar alma süreçlerine aktif katılımını sağlamak için pek çok mekanizma geliştirmiştir. Bu mekanizmaların bir kısmı ülke genelindeki tüm yerel yönetim kuruluşlarında uygulanırken kimi yerel yönetimlerde kendi yerel demokrasi uygulamalarını hayata geçirmiştir. Antalya Muratpaşa Belediye'nin geliştirdiği dijital demokrasi platformu olan "Komşu Meclisi" uygulaması da bu çerçevede değerlendirilmektedir.

\section{KAVRAMSAL ÇERCEVE: YEREL YÖNETIMLER}

Kamu yönetiminin önemli ve vazgeçilmez boyutunu oluşturan yerel yönetimler, belli bir alanda/bölgede yaşayan vatandaşların, yerel-ortak ihtiyaçlarını karşılamak amacıyla merkezi yönetim dışında kurulmuş olan kendi organları olan yönetim birimleridir (Güler, 2009:279; Y1lmaz vd., 2012:21; Kaypak vd., 2017:1800). Yerel yönetimlerin ortaya çıkışı ile ilgili kesin bir bilgi bulunmamakla birlikte insanların örgütlenmeye ve birlikte yaşamaya başladıkları Mezopotamya'nın ilk tarım toplumlarına kadar gitmektedir (Coşkun, 2016:5). Antik Yunan'da "Site" ve "Polis" denilen kent devletleri ile Roma İmparatorluğu'ndaki “municipe" ler bugünkü yerel yönetimlerin temel dayanağını oluşturmuştur (Çicek, 2014:54-55). Bu dönemdeki yerel yönetimler daha çok savunma ve adalet gibi merkezi yönetimler tarafından yerine getirilen görevleri üstenmişlerdir (Keleş, 2012:33). Modern anlamda yerel yönetimler ise Ortaçağ'da feodal devletlerin yıkılması sonucu merkezi yönetimlerin zayıflamasından sonra (Arslan, 2016:27; Demir ve Karakütük, 2003:68), XII. yüzyılda liman kentlerinin ekonomik birer birim haline gelmeleri ve sosyal sınıfların gelişmesine bağlı olarak canlanan kent hayatı üzerine inşa edilmiştir (Pirenne, 2003'den akt.: Sobac1 ve Köseoğlu, 2016:13). Bu dönemde toplumsal dönüşüm ve ticari gelişmeler sonucu ortaya çıkan ve kentlerin özgürleşmesini sağlayan, hukuksal yapıdaki toplumsal kurum olan komünler (yerel yönetim birimleri) yerel yönetimlerin kurumsallaştığı ilk örnekler olarak karşımıza çıkmaktadır (Koç, 2015:10; Karaarslan, 2007:14). XVI. yüzyılda ulus devletlerin ortaya çıkmasıyla birlikte komünlerin gücü azalmış (Çiçek, 2014:56); bunun sonucunda da komünler uzun bir süre ara kurumlar olarak varlıklarını sürdürmüşlerdir. XIX. yüzyılda devlet içinde ayrı bir tüzel kişilik kazanmaya başlayan yerel yönetimler, bu dönemde yapılan düzenlemelerle birlikte merkezi yönetimin birer yerel ofisi şeklinde hizmet vermişlerdir (Ökmen ve Parlak, 2010:25-26). Örneğin, bu dönemde İngiltere'de yerel yönetimler, kentin tüm sorunlarına çözüm bulmayı amaçlamış; ABD'de ise yerel yönetimler yerel kamu hizmetinin yanında, bu birimlere kendi kendilerini yönetme hakkı verilmiş ve yerel yönetimlerde özerklik uygulamalarının önü açılmıştır (Sobacı ve Köseoğlu, 2016:13). II. Dünya Savaşı sonrasında sosyal devlet anlayışının gelişmesine paralel olarak yerel yönetimlerin ülkeler içindeki önemi ve konumu güçlenmiş bu dönemde yerel yönetimler 
ERDOĞAN, Oğuzhan - Yerel Politikaların Şekillenmesinde Dijital Demokrasi Uygulaması: Antalya Muratpaşa Belediyesi Komşu Meclisi

vatandaşlara merkezi yönetimin sunduğu hizmetlerden daha fazlasını sunarak bir nevi refahın yeniden paylaşılmasını sağlayan birimler haline gelmişlerdir (Keleş, 2012:40, Sobac1 ve Köseoğlu, 2016:14).

Bugünkü anlamıyla yerel yönetimler kavramı ilk olarak 1950'li ve 1960'lı yıllarda Fransa ve İngiltere'nin kolonilerine, merkezi yetkilerden bir kısmını devretmek amacıyla gerçekleştirdikleri düzenlemeler sonucu ortaya çıktığı ifade edilmektedir (Falay vd., 2009'dan akt.: Arslan, 2016:27). 1970'li y1llarda ise, yerel yönetimlerde siyasi, mali ve idari özerklikler daha çok kendini göstermeye başlamış ve yerel yönetimlerde yerel demokrasi uygulamaları gelişmeye başlamıştır (Bardhan ve Mookherjee, 2006'dan akt.: Koç, 2015:14). 1980'li yıllara gelindiğinde özelleştirmeler, neo liberal politikalar, yeni kamu yönetimi yaklaşımı çerçevesinde devletin küçültülmesine yönelik politikaların geliştirilmesi yerel yönetimlerin daha etkin bir hale gelmesinin önünü açmıştır (Aykaç, 1999:2). 2000'li yıllardan sonra ise küreselleşme, demokratikleşme çabaları, ekonomideki dönüşüm, bilgi-iletişim alanında yaşanan gelişmeler yerel yönetimlere de yansımış ve bu dönemde yerel yönetimler demokrasinin önemli bir unsuru olmaya başlamıştır (Akbulut ve Göküş, 2017:80-81). Günümüz yerel yönetimlerini genel anlamda geçmişteki kent yönetimlerinin ve komünlerin modern devletle uyumlaştırılmış uzantısı olarak nitelendirmek mümkündür (Özel, 2013:50).

Tanım olarak bakıldığında, yerel yönetimler, belli bir coğrafi sınır içerisindeki yerel nitelikteki kamu hizmetlerinin, merkezi yönetime bağlı olmayan ve karar organları halk tarafından seçilen kamu kuruluşları eliyle yürütülmesidir (Ulusoy ve Akdemir, 2010:55). Bu birimlerin kendi tüzel kişilikleri, seçilmiş karar ve yürütme organları ile belli bir özerklikleri ve anayasal bir takım güvenceleri mevcuttur (İpek, 2016:17). Yerel yönetimlerin gücü ve etkinliği, o ülkedeki demokrasinin gelişmişliği ile ilgilidir. Günümüzde yerel yönetimler demokrasinin güçlendirilmesi ve yaygınlaştırılması noktasında popülerliklerini korumaktadır. Yerel yönetimler sadece bir hizmet kuruluşu olarak değil aynı zamanda demokratik siyasi kurumlar olarak birçok işlevi yerine getirmektedir (Parlak, 2006:338). Yerel yönetimler, demokrasinin olmazsa olmazı olan halkın yönetime katılımının sağlanması ve yerel politika üreterek kalkınmaya büyük katkıda bulunmakla birlikte çağa uygun olarak kurumsal yapılarını revize etmektedir (Erdoğan, 2019a:44-45; Bulut ve Y1lmaz, 2019: 732). Ayrıca yerel yönetimler siyasal karar alma mekanizmalarının etkinliğini arttırmakta ve siyasi sistemin meşruluğuna önemli katkılar sunmaktadır. Bunun yanında idari yapının demokratikleşmesi ve şeffaflaşmasına da katkı sağlamaktadır (Kaboğlu, 2000:17).

\section{YEREL POLITIKA}

Politika kavram olarak bir hükümetin, şirketin ya da bir ailenin başındaki sorumlu kişi/lerin aldığı karar ya da elde edilecek temel hedeftir (Akman, 2019:5). Kamu politikası ise kamu idaresi tarafindan uygulanan ve hükümet tarafindan karar verilen kanunlar ya da düzenlemeler aracilığıyla, idarecilerin toplumsal sorunlara yaklaşımını ortaya koyan ve vatandaşların belirli sorunlarına çözüm bulmak için almış olduğu kararlar ve izlenecek yollardır (Dye, 1987:2; Eryılmaz, 2013:14-15). Kamu politikalarını oluşturma kaynağı temelde kamu yönetimidir. Ancak kamu politikalarının oluşum sürecinde devlet dışında etkili olan bazı faktörler de mevcuttur. Aile, siyasi partiler, sivil toplum kuruluşları, üniversiteler, basın-yayın kuruluşları, şirketler, düşünce kuruluşları, uluslararası kuruluşlar (İMF vb.), sendikalar ve vatandaşlar politika oluşum sürecinde önemli roller oynamaktadır (Göçoğlu, 2014:10).

Kamu idareleri tarafından uygulanan kamu politikaları yerel ya da ulusal düzeyde uygulanmaktadır. Yerel düzeyde ortaya çıan problemlerin tespiti ve çözümünde ya da yerel nitelikteki kamu hizmetlerinin sunumunda yerel yönetimler önemli görevler üstlenmektedir. $\mathrm{Bu}$ çerçevede, yerel düzeyde oluşmuş olan sorunların tespiti ve çözümü noktasında yerel politikaların oluşturulmasında yerel yönetimler kilit rol oynamaktadır. Yerel yönetimlerin merkezi yönetimden farklı olarak ürettiği politikalara yerel politika denilmektedir. Bu tanımdan da anlaşılacağı üzere burada politika kavramı daha dar çerçevede "yapılan iş" ve "icatlar"la sınırlanmıştır (Sanay, 2019:11). 5393 sayılı Belediye Kanunun 14. maddesinde belediyenin görevleri sayılmıştır. Bu görevlerin yerine getirilmesi noktasında belirli bir politikalara ihtiyaç duyulacağı ortadadır. Yine aynı kanunun 14. maddesinin $b$ fikrasında "hizmetlerin yerine getirilmesinde öncelik sirası belediyelerin mali durumu ve hizmetin ivediliği dikkate alınarak belirlenir" (Belediye Kanunu, md.14) şeklinde belirli şartlar altında politikaların belirlenip hangisinin daha öncelikli ve acil konumda olduğunun takdiri ilgili yerel yönetim kuruluşlarına bırakılmıştır (Sanay, 2019:11). Yerel politikaların belirlenmesinde yerel düzeydeki pek çok aktör rol oynamaktadır (Kuşçu, 2018:55). Yerelde kentlerin seçilmiş meclisleri yerel düzeyde politika yapımında önemli sorumluluklar almaktadır (Municipal Research \& Services Center of Washington, 1999:1). Yerel politika; yerel düzeydeki siyasi aktörlerin ve paydaşların kısa ya da uzun vadeli üretmiş oldukları hizmetler, iş ve işlemlerin toplamıdır. Başka bir tanımda yerel politika, yerel yönetim birimlerinin vatandaşların ortak yerel kamu hizmetlerinin ve 
toplumsal, kültürel ve ekonomik içerikli bütün kararlarını ve uygulamalarını içermektedir (Alkan, 2000:4). Bu politikalar belirli bir yerel ölçek ve sınır dâhilinde üretilen özel politikalardır. Bu politikaların üretim aşamasına bakıldığında yerel ölçekte söz sahibi olan, yönetimde doğrudan ya da dolaylı payı olan, sürece etki edebilen tüm aktörlerin toplam icrası yerel politikayı oluşturmaktadır. Yerel düzeyde örgütlenen STK'lar, medya, vakıf ve dernek gibi kuruluşlar yerel siyasetin belirlenmesinde yer alan önemli aktörler olarak karşımıza çıkmaktadır (Kuşçu, 2018:56). Diğer taraftan yerel yönetimler vatandaşları politik karar alma sürecine dahil edebildiği ölçüde demokratiktir. Yerel yönetimlerin uygulayacağı politikaları belirleme noktasında yereldeki vatandaşların bu politika belirleme sürecine çeşitli yollarla dahil edilebilmesi yerel düzeyde ihtiyaç duyulan mal ve hizmetlerin doğru olarak belirlenebilmesi açısından da önemlidir.

\section{YEREL DEMOKRASİ VE UYGULAMALARI}

Yerel yönetimlerin demokrasi ile uyumlu olmadığını savunan görüşler olmakla birlikte genel olarak kabul gören düşünce, yerel yönetimlerin demokrasinin uygulama alanı ve demokrasinin ayrılmaz bir parçası olduğu yönündedir (Özden, 2014:25). Bu bağlamda demokrasi kavramını tanımlarken ve bir ülkede demokrasiyi geliştirmeye çalışırken bunun yerel yönetimlerden bağımsız olamayacağı da aşikârdır. Keza yerel yönetimlerin temelinde de yerel demokrasinin değerleri yatmaktadır (Kalabalık, 2005:47). Çünkü yerel yönetimler halka en yakın idari kurum olarak halkın kendisini yönetmesine olanak veren bir yapıdır (Belli, 2015:70). Demokrasi kavramının tanımını yapmak ne kadar zor ve karışıksa, yerel demokrasi kavramını tanımlamak da o kadar güçtür. Hill (1974:71) yerel demokrasiyi "vatandaşları doğrudan etkileyen, gerçek ve somut sorunlarla günlük

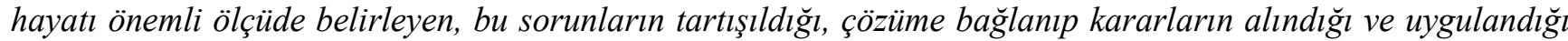
küçük ölçekli bir dünya" olarak tanımlamıştır. Avrupa Konseyi tarafından 1992 yılında benimsenen ve Türkiye'nin de kabul ettiği Avrupa Kentsel Şartı'nda yerel demokrasi; “Kentsel gelişmenin temeli, özerk ve mali bă̆ımsızlı̆̆ı olan yerel yönetimlerde halkın doğrudan katılımının să̆lanmasıdır” (Avrupa Kentsel Şartı, mad.3/3). Başka bir tanımda ise yerel demokrasi, demokrasi kavramının sahip olduğu değerlerin yerel yönetimler için geçerli kılınması, halkın yerel karar alma süreçlerine doğrudan ya da dolaylı katılımı olarak tanımlanmaktadır (Pustu, 2005:127). Demokrasinin yerel demokrasi niteliği kazanması, demokrasinin sivil toplum kuruluşları ve geniş halk kitleleri tarafından benimsenmesine ve demokrasinin halk tarafindan istenmesine bağlıdır (Aykaç, 2003:9). Avrupa Kentsel Şartı'ndan hareketle yerel yönetimlerde demokrasinin sağlanabilmesi için yerel yönetimlerin özerkliğinin ve mali bağımsızlığının da sağlanmış olması gerekmektedir (Çelik vd., 2008:93).

Yerel demokrasinin olmazsa olmazı "kamu işlerinin ve kamu hizmetlerini yönetimine bütün vatandaşların demokrasinin bir gereği olarak doğrudan katılımının sağlanmasıdır" (Öztürk, 1994:405). Seçimlerde oy vermenin dışında vatandaşların fikir, istek ve şikâyetlerini yerel yetkililere ulaştırmasına ve politika yapma süreçlerinde katılmalarına imkân veren, yerel politika üretimine katı sağlayan çeşitli mekanizmalar vardır. Başka bir ifadeyle vatandaşların yerel ihtiyaçlarını belirlemek, kentin sorunlarına çözüm üretmek, siyasi, ekonomik ve idari iradenin, grupların, toplulukların ve sivil toplum kuruluşlarının ortak çıkarlarını belirlemek, yerel halkın düşünce, istek ve şikâyetlerini yerel yetkililere ulaştırmak amaciyla birçok mekenizma oluşturulmuştur (Tokgöz, 2011'den akt.: Çetinkaya ve Korlu, 2012:98). Dünya genelinde ülkeler yerel girişim (inisiyatif), referandum, halkın vetosu, geri çağırma, meclis toplantılarına katılım, kent konseyleri, yerel topluluk meclisleri, mahalle meclisleri, ihlal bildirme ve bilgilendirme hakkı ve katılımcı bütçeleme gibi bir takım yerel demokrasi uygulamaları ile vatandaşların yerel demokrasiye katılımını teşvik etmektedir. $\mathrm{Bu}$ mekanizmalar vatandaşları yerel karar alma süreçlerinin aktif bir paydaşı haline getirmektedir.

Tablo 2. Dünya Genelinde Uygulanan Yerel Demokrasi Uygulamaları

\begin{tabular}{|c|c|c|c|}
\hline Geri Çağırma & Yerel Girişim & Referandum & Katılımcı Bütçeleme \\
\hline İhlal Bildirme ve Bilgilendirme Hakk1 & Dilekçe Hakkı & Denetim İsteme ve Dava Açma Hakkı & Ward (Semt) Komiteleri \\
\hline Semt Toplantıları & Hesapların Yayınlanması & Sektör Çalışma Grupları & Açık Kapı Uygulamalar \\
\hline Yabancılar Meclisi & Meclis Toplantılarına Katılım & Belediye Hizmetlerine Gönüllü Katılım & Komşu Meclisleri \\
\hline Sosyal Medya & Topluluk Anketleri & E-Devlet Uygulamaları & Mahalle Meclisleri \\
\hline Kent Konseyleri & Online Forumlar & Yerel Topluluk Meclisleri & Halk Toplantıları \\
\hline Halk Günleri & Proje Demokrasileri & Yurttaş Kurulları & Telefon Yöntemi \\
\hline Kamu Oyu Yoklamaları & Yerel Seçimler & - & - \\
\hline
\end{tabular}


Dünya genelinde uygulanan yerel demokrasi uygulamalarından bazıları şunlardır:

- Geri Çağırma: Vatandaşların seçtikleri yöneticileri, görev sürelerinin dolmasını beklemeden görevlerinden alınmalarını sağlayan güçlü bir katılım mekanizmasıdır. Geri çağırma yetkisi, yerel yönetim biriminin kayıtlı seçmenleri tarafından kullanılabilmektedir. Geri çağırma işleminde geri çağırma işlemi uygulanacak yerel yönetici için önce belirli sayıdaki seçmenden imza toplanmakta, daha sonrada bu toplanan dilekçelerle birlikte geri çağırma referandumu yapılmaktadır (Erdoğan, 2019a:99).

- Yerel Inisiyatif (Girişim): Yerel inisiyatif, yerel yönetimlerde kayıtlı seçmenlerin herhangi bir yasayı doğrudan önerebildiği, yürürlüğe koyabildiği veya değiştirmesini sağlayabildiği yasal bir süreçtir. Yerel girişim ve referandumun gücü, yerel yönetim birimlerinin kayıtlı tüm seçmenleri tarafindan uygulanabilmektedir (Choi vd., 2013:42).

- Yerel Referandum: Yerel referandum, yerel yönetim birimlerinin kayıtlı seçmenleri tarafindan yürürlüğe konan herhangi bir yasanın, düzenlemenin ya da uygulamanın onaylanması, değiştirilmesi veya reddedilebilmesi için uygulanan yasal bir süreçtir (Erdoğan, 2019a:155).

- Yerel Topluluk Meclisleri: Dünya genelindeki hemen hemen her yerel yönetim biriminde sosyal politika alanı için farklı meclislerin kurulduğu görülmektedir. Belediye meclisleri, belediye başkanının önerisi doğrultusunda veya vatandaşların talebi üzerine halka açık mahalle toplantıları gerçekleştirmektedir. $\mathrm{Bu}$ meclisler, yerel kamu hizmetlerinin denetlenmesinden, vatandaşların belediye düzenlemelerine uymasından ve belediye çalışmalarının sağlıklı bir şekilde yürütülmesinden sorumludur. Yerel topluluk meclisleri, akredite edilmiş temsilcileri aracıllı̆ıyla belediye meclisinin toplantılarında konuşma hakkına sahiptirler (Erdoğan, 2019a:132).

- Ihlal Bildirme (Rapor Etme) ve Bilgilendirme Hakkl: Vatandaşlar, bireysel ya da toplu olarak kent genelinde yaşanan ihlaller hakkında yazılı şikâyet etme hakkına sahiptir ve belediyelerde yasal süreler içerisinde bu şikâyetlere cevap vermek zorundadır (Erdoğan, 2019a:132).

- Katılımcı Bütçeleme: Katılımcı Bütçeleme, 1996 yılındaki Habitat II konferansında, Brezilya'nın 26 eyaletinden biri olan Rio Grande do Sul'un başkenti Porto Alegre'nin "Ormental Participativo (Katılımc1 Bütçe)" adlı projesinin (Crabtree, 2014:452), "kentsel yönetimde en iyi uygulama" alanında ödül almasından sonra, dünyanın farklı ülkelerin de uygulanmaya başlanmıştır (Hordijk, 2009:43). Bu sistemin amacı, yerel düzeyde mali ve politik karar verme sürecinde demokrasi ve verimliliği artırmak için yerel yönetimlerin bütçe sürecine vatandaşın katılımını sağlamaktır. Katılımcı bütçeleme, yerel yönetimlerin bütçesine eşit olmayan bir şekilde etki etme sorununa rağmen, yerel politika oluşturma sürecinde vatandaş katılımının kalitesini arttırdığını kanıtlamıştır (Choi vd., 2013:44).

- Denetleme Ísteme ve Dava Açma Hakkı: Dünya genelinde pekçok yerel demokrasi uygulaması gelişmiştir. Bunlardan biri de denetleme isteme ve dava açma hakkıdır. Örneğin Kore'de vatandaşlar bir yerel yönetimin veya belediye başkanının yaptığı hukuka aykırı işlemleri veya o yerel yönetim biriminde yapılan yolsuzluklarla ilgili olarak 19 yaş ve üstü vatandaşların imzaları ile iller için ilgili bakandan ve alt düzey yerel yönetimler için belediye başkanı veya validen soruşturma açılmasını ve denetim yapılmasını talep edebilmektedir (Choi vd., 2013:42-43).

- Yerel Yönetim Sektör Çalışma Grubu: Özel sektör, yerel siyaset ve karar alma mekanizmasına katk1 sağlamaktadır. Özel sektör, sivil toplum kuruluşları, üniversiteler ve yerel yönetimler bir araya gelerek yerel politikaya katkı sağlamak, yönetişim ve hizmet sunumu gibi meseleleri görüşmek amaciyla Yerel Yönetim Sektörü Çalışma Grupları oluşturmaktadır (Erdoğan, 2019a:180-181).

Elbette dünya genelinde uygulanan yerel demokrasi uygulamaları bunlardan ibaret değildir. Her ülke kendine özgü yerel demokrsi uygulamaları ile vatandaşların politik karar alma süreçlerini katılımını teşvik etmektedir. Bununla birlikte son yıllarda özellikle bilgi-iletişim teknolojilerinin demokrasi ile bütünleşik şekilde kullanılmasıyla dijital demokrasi kavramı demokrasinin daha açık ve hesap verebilir bir yapıya kavuşmasında önemli roller üstlenmektedir (Güler ve Şahnagil, 2017:18). Vatandaşların bilgi toplamasına ve paylaşmasına geniş ölçüde imkân sağlayan dijital demokrasi, bilgi iletişim teknolojilerinin geliştirdiği stratejiler çercevesinde vatandaşlar için kamusal meseleleri tartışarak, çözümler üreten müzakereci ortamlar yaratmaktadır (Çetin, 2010: 4). 


\subsection{Türkiye'de Yerel Demokrasi Uygulamaları}

Toplumsal hayatta ortaya çıkan uyuşmazlıkların çözülmesinde yerel halkın katılımı ve seçmenlere karşı hesap verebilme sorumluluğu önemli yer tutmaktadır. Tüm bu olguların en kolay yerine getirilebileceği yerler ise yerel yönetim birimleridir (Mutlu, 2015:476). Bir ülkede yerel demokrasinin hayata geçirilmesi ise merkezi yönetimin idari ve mali açıdan yerel yönetimlere sağladığı özgürlüklerle de yakından ilgilidir (Akman, 2017:5). Türkiye'de vatandaşların yerel yönetimlere ve politika yapım sürecine katılımında referandum, stratejik plan, meclis toplantılarına katılım, halk günleri, açık kapı uygulaması, online forumlar, e- devlet uygulamaları, kent konseyleri, kamuoyu yoklamaları, halk meclisleri, yabancılar meclisi, komşu meclisi, mahalle meclisi, bilgi edinme ve dilekçe hakkı gibi birçok mekanizmanın kullanıldığı görülmektedir (Erdoğan, 2019a:210-211; Erdoğan, 2019b:299-301).

- Referandum: Referandum yerel yönetimler tarafindan sikça kullanılan bir yerel demokrasi örneğidir. Özellikle yerel yönetimler tarafından yapılan alt ve üst yapı yatırımları ile halkı ilgilendiren önemli kararlarda vatandaşların etkin bir rol oynaması için çeşitli referandumlar düzenlenmektedir.

- Meclis Toplantılarına Katılım: Belediye ve il genel meclis toplantıları kural olarak kamuya açık bir şekilde yapılmaktadır. Meclis toplantılarının halka açık yapılması, vatandaşların konu hakkındaki bilgi eksikliğini gidermekte, birinci elden kendi sorunlarını ve önerilerini yöneticilere aktarmasını sağlamakta ve basınında etkisiyle meclis toplantısına katılan vatandaşların sordukları sorular ve dile getirdikleri sorunlar meclis kararlarını etkilemektedir (Yalçındağ, 1996:136).

- Kent Konseyleri: 5393 sayılı Belediyeler Yasası ile kurulmuş olan Kent Konseyleri, kentteki tüm paydaşları bir araya getirerek; ortak bir akıl oluşturmak amacıyla kurulmuştur. Kent konseyleri;
"bulundukları il ve ilçelerdeki belediyeler, üniversiteler, kamu kurum ve kuruluşu temsilcileri, muhtarlar, siyasi partiler, sendikalar, vakıflar, dernekler ve meslek odalar temsilcilerinden oluşarak toplumda çok sesliliği teşvik etmekte, vatandaşları politika yapım sürecine dâhil etmekte, sosyal yardımlaşma ve dayanışma duygularını kuvvetlendirmekte, hesap verme, katılım ve şeffaflı gibi iyi yönetim ilkelerinin gerçekleştirilmesi için önemli katkılar sağlamaktadır".

5393 sayılı yasa (md.76) ile kentsel paydaşların bir arada olduğu ve aldıkları kararların meclis gündemine taşınma olanağının ortaya çıktığı yönetsel bir mekanizmaya sahip olmuştur (Mecek, 2018:1548). Kent konseyleri, kent konseyi genel kurulu, kent konseyi başkanı, kent konseyi yürütme kurulu, kent konseyi genel sekreterliği, kadın meclisi, gençlik meclisi, engelliler meclisi, çocuk meclisi, yabancılar meclisi ile çeşitli çalışma gruplarından oluşmaktadır.

- Belediye Hizmetlerine Gönüllü Katılım: Belediyeler Yasasının 77. maddesine göre;

"Belediye; sağllk, eğitim, spor, çevre, sosyal hizmet ve yardlm, kütüphane, park, trafik ve kültür hizmetleriyle yaşlılara, kadın ve çocuklara, engellilere, yoksul ve düşkünlere yönelik hizmetlerin yapılmasında ilgili yerel yönetim biriminde dayanışma ve katılımı sağlamak, hizmetlerde etkinlik, tasarruf ve verimliliği artırmak amacıyla gönüllü kişilerin katılımına yönelik programlar uygulamaktadır".

- Bilgi Edinme ve Dilekçe Hakkl: 1982 Anayasasıyla vatandaşlara bilgi edinme ve dilekçe hakkı tanınmıştır. Bu bağlamda vatandaşların yerel yönetim ve kamu kuruluşları ile ilgili dilek ve şikâyetleri hakkında idari makamlara başvuruda bulunmaları ve kendileri veya faaliyet alanlarıyla ilgili konularda bilgi isteme hakkına sahiptir. İlgili yerel yönetim birimleri de vatandaşların bilgi edinme dilekçelerine otuz (30) gün içerisinde cevap vermek zorundadır.

Türkiye'de uygulanan tüm bu yerel demokrasi uygulamalarının yanında her belediye kendine uygun bir şekilde vatandaşları yerel politika sürecine dâhil etmek için birbirinden farklı mekanizmalar da kullanabilmektedir. Halk günlerinde vatandaşlar belediyelerin belirlediği günlerde belediye başkanı ile yüz yüze görüşebilmekte, mahalle ve halk meclisleri ile özellikle mahallelerinde yaşayan vatandaşlar istek ve önerilerini belediyelere iletebilmekte, online forumlar ve kamuoyu yoklamaları ile yerel politika süreçlerine vatandaşların aktif katılımı sağlanmaktadır (Erdoğan, 2019:210-211). 


\section{TÜRKIYENIN ILK DIJJTTAL DEMOKRASI PLATFORMU: MURATPAŞA BELEDIYYESİ KOMŞU MECLISI UYGULAMASI ${ }^{1}$}

Demokratik yerel yönetim anlayışından hareketle kurulan "Komşu Meclisi" uygulaması komşuların (kent sakinlerinin) kendilerini ve kenti ilgilendiren tüm konularda görüş ve öneri sunmalarını, düşüncelerini ifade etmelerini ve karar alma süreçlerine doğrudan katılım sağlamalarını amaçlayan bir dijital demokrasi platformu olarak "www.komsumeclisi.com" adresi üzerinden 21 Şubat 2020 tarihi itibarıyla hizmete başlamıştır. Uygulama kapsamında ilk aşamada, dijital demokrasi ile ilgili ulusal ve uluslararası akademik-profesyonel makale ve yayınların taraması yapılmıştır. Yapılan tarama sonucunda dünyadaki dijital demokrasi uygulamaları incelenip, Anadolu'nun kadim kültür ve geleneği esas alınarak projenin yaşama geçme koşulları belirlenmiştir. Bu kapsamda İzlanda-Reyjavik, Fransa-Paris ve İspanya-Madrid gibi kentlerde uygulanan örnekler de dikkate alınmıştır. Uygulama Muratpaşa Belediyesi Halkla İlişkiler Müdürlüğüne bağlı Dijital Medya Ekibi ve Bilgi İşlem Müdürlügüne bağlı yazılım ekibi tarafından yürütülmektedir. Dijital Demokrasi Platformu, MERNİS adresleri esas alınarak, Antalya ili Muratpaşa İlçesinde yaşayan ve (online) üyelik başvurusunda bulunarak üyelik sözleşmesini kabul eden komşulardan (vatandaşlardan) oluşmaktadır. Kapsayıcı hedef kitlesi ise 510.368 kent sakininden oluşmaktadır.

Belediye yönetimince belirlenen konular platform üzerinden on-line olarak forum içerisinde tartışlabilmekte, vatandaşlar kent ile ilgili öneri sunulabilmekte ve gerektiğinde oylama yapabilmektedir. Oylama sonucu ise, ilgili yetkili organlara/kurullara ve belediye meclisine öneri olarak sunulmaktadır. Üyeler tarafından önerilen konu başlıklarından uygun olanlar da belediye tarafindan forumda tartışmaya açılabilmektedir. Dijital Demokrasi Platformu Komşu Meclisinde öne çıkan, meclis tarafından kabul edilen öneri ve projeler belediyenin ilgili birim ya da kuruluşlarına gönderilebilmektedir. Üyelik sözleşmesini imzalayan komşular, forumlarda yapılan tartışmalarda kullanılacak ifadelerin düşünce ve ifade özgürlüğ̈̈ kapsamında kalacağını, bununla ilgili her türlü hukuki ve cezai sorumluluğun kendisine ait olduğunu kabul ve taahhüt etmektedir. Aynı şekilde; üyeler, platformdaki üçüncü kişilerin her tür söz ve eylemlerinden dolayı Muratpaşa Belediye Başkanlığı'nın hiçbir sorumluluğu bulunmadığını da kabul ve taahhüt etmektedir. Küfür, hakaret ve tehdit içerikli yorumlar ise belediye yetkilileri tarafından platformdan kaldırılmaktadır.

Bu uygulamada, Platform Mernis Sistemi ile kişinin ikamet adresi doğrulanıp isim ve soy isim bilgileri ekrana taşınmaktadır. Kullanıcılar, şifrelerini belirleyip telefonlarına gelen kısa mesaj aracılı̆̆ıyla platforma kayıt işlemini tamamlamaktadır. Sistem kullanıcıların Kişisel Verileri Koruma Kanunu Kapsamı'nda aydınlatma metni ve rıza gösterme işlemini de bu aşamada yapmaktadır. Böylelikle hem gerçek kent sakinlerinin platformda olması garanti altına alınmış olmakta hem de dijital medyada trol olarak bilinen kimliklerini saklayarak, kişi ve kurumlara saldırgan davranışlarda bulunan oluşumlardan platformun korunması amaçlanmaktadır.

Tablo 1. Türkiye'nin İlk Dijital Demokrasi Platformu Komşu Meclisi’nde Yer Alan Uygulamalar

\begin{tabular}{|c|l|}
\hline UYGULAMA & \multicolumn{1}{c|}{ AÇIKLAMASI } \\
\hline Oylama Sayfası & Kenti ilgilendiren proje ve uygulamaların oylandığı sayfa. \\
\hline Mahalle Meclisleri & Muratpaşa'nın 55 mahallesinin adını taşıyan mahalle sakinlerinden oluşan meclis. \\
\hline Bir Fikrim Var Bölümü & Vatandaşların kendi projelerini ve fikirlerini iletebileceği bölüm. \\
\hline Komşu Formu & $\begin{array}{l}\text { Oylamaya sunulacak konuların herkes tarafından en az } 3 \text { gün boyunca tartışılmasını sağlayan } \\
\text { forum. }\end{array}$ \\
\hline
\end{tabular}

Kaynak: Yazar tarafindan oluşturulmuştur.

Şubat 2020'de hayata geçirilen Komşu Meclisi uygulaması dört bölümden oluşmaktadır. Komşu Meclisi ilk olarak bir "oylama sayfası" yla açılmaktadır. Oylama yapıldıktan sonra alanda açılan kutucuğa istenildiği takdirde yorum da yapılabilmektedir. Ana sayfada oylama konusu ve oylamaya katılım için kalan süre gösterilmektedir. Uygulamada Muratpaşa'nın 55 mahallesinin adını taşıyan "Mahalle Meclisleri", oylamaya sunulacak konuların tartışıldığı "Komşu Formu" ve Muratpaşalıların fikir, öneri ve projelerini iletecekleri "Bir Fikrim Var" bölümü bulunmaktadır. Mahalle özelindeki oylamalarda burada mahalle meclisi bölümünde

1 Bu çalışmada “Komşu Meclisi” uygulaması ile ilgili tüm veri ve kaynaklar Muratpaşa Belediyesinden özel olarak alınmıştır. Çalışmanın şekillenmesine katkı sunan Muratpaşa Belediyesi Halkla İlişkiler Müdürlüğü ve Bilgi İşlem Müdürlüğü çalışanlarına teşekkürü bir borç bilirim. 
yapılmaktadır. Örneğin Muratpaşa'ya bağlı Balbey Mahallesinde belediye bir hizmet yapacaksa ve bunu halka soruyorsa uygulamadaki mahalle meclisleri kapsamında sadece o mahallenin oy kullanması sağlanmaktadır.

Kayıt işleminden sonra girilecek olan dijital platformun hizmet başlıkları şöyle belirlenmiştir;

- Anasayfa: Kullanıcı giriş sayfasında girdiğinde o anda oylamadığı bir konu varsa ilk olarak onu görmektedir. Oylamasını yaptıktan sonra vatandaş dilerse oylama hakkında görüşünü bildirmektedir. Bu görüşler Anasayfa oylama ekranı altında yer almaktadır. Anasayfada aynı zamanda yapılan oylama için kalan süreyi gösteren bir sayaç bulunmaktadır. Mobil telefon uyumlu arayüz, aşağı kaydırıldıkça Mahalle Meclisleri ve Yaşamın İçin'den sayfalarına ait içerikler de görünmektedir.

Görüntü 1. Dijital Komşu Meclisi Oylama Uygulaması Ekranı

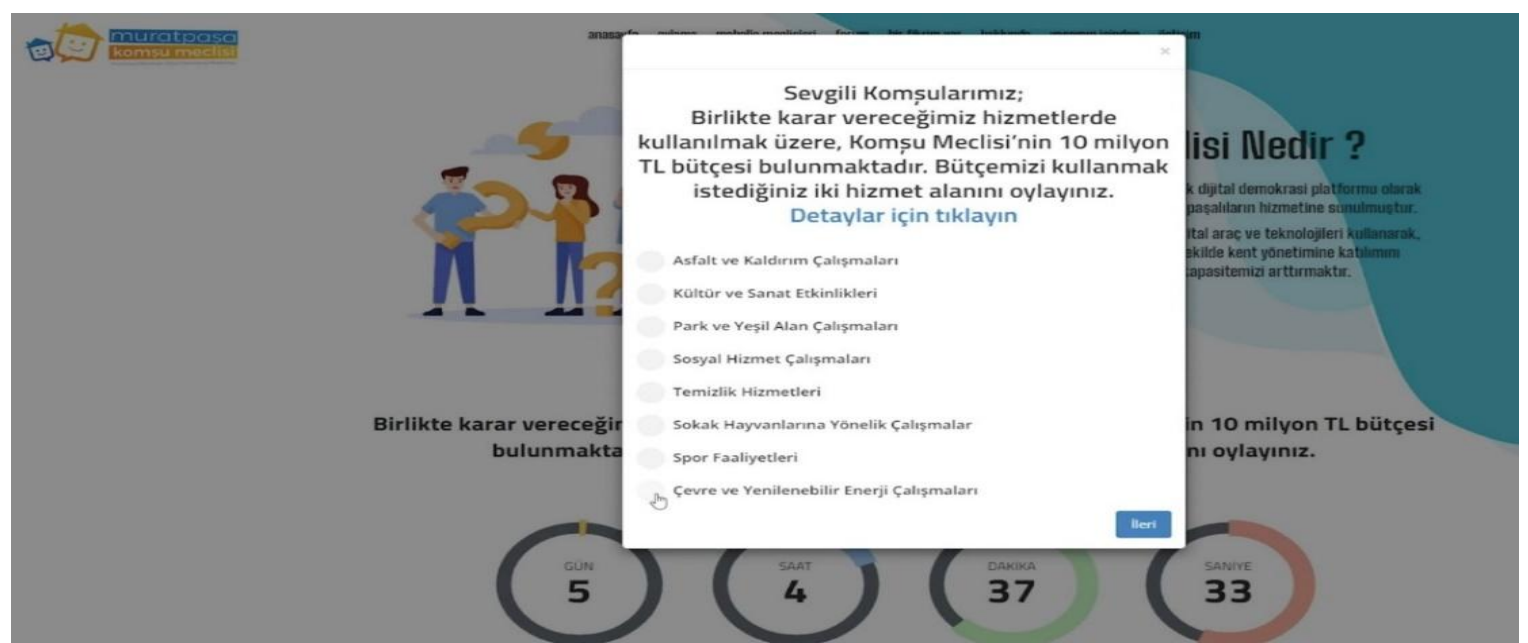

Kaynak: https://komsumeclisi.com/ (Erişim Tarihi: 05.03.2020).

- Oylama: Bu sayfada yapılan oylamanın seçeneklere yönelik yüzdelik dağılımı ve geçmişte yapılan oylamalar ve sonuçları görülmektedir. Yazılım uzmanları tarafından geliştirilen bir algoritma genel konuların oylamasını, kullanıcıların bulunduğu mahalledeki nüfus oranın genel içindeki payı dikkate alınarak, nüfusun yoğun olduğu ve düşük olduğu mahalleler arasında adil bir oylama sistemi geliştirilmiştir.

Görüntü 2. Dijital Komşu Meclisi Oylama Uygulaması Sonuç Görüntüleme Ekranı

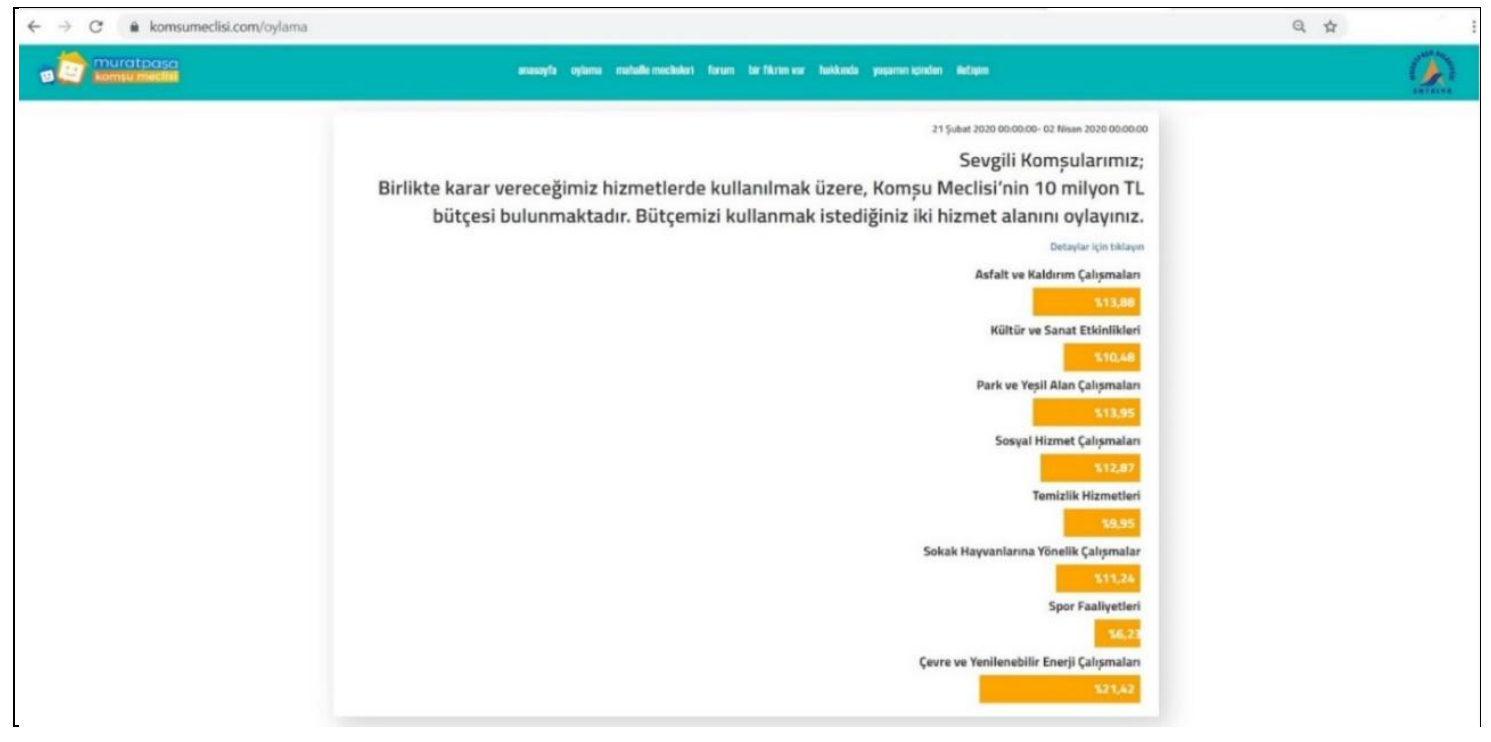

Kaynak: https://komsumeclisi.com/ (Erişim Tarihi: 05.03.2020).

- Mahalle Meclisleri: Bu sayfada Muratpaşa'da bulunan 55 mahalle için ayrı ayrı mahalle meclisleri bulunmaktır. Yine MERNiS ile doğrulanan adres bilgisi nedeniyle kullanıcılar ikamet ettikleri mahalle meclislerinin doğal üyesi olmakta, sadece kendi mahallerinde oy kullanabilmekte ve kendi mahalleri dışında herhangi bir mahalle meclisinde oy kullanamamaktadır. Mahalle meclislerinde mahalle 
ERDOĞAN, Oğuzhan - Yerel Politikaların Şekillenmesinde Dijital Demokrasi Uygulaması: Antalya Muratpaşa Belediyesi Komşu Meclisi muhtarının bilgileri, belediyenin mahalleye yaptığı yatırımların kısa bir özeti ve oylamaya dair bir konu varsa o konunun oylama modülü bulunmaktadır.

Görüntü 3. Dijital Komşu Meclisi Forum Uygulaması Ekranı

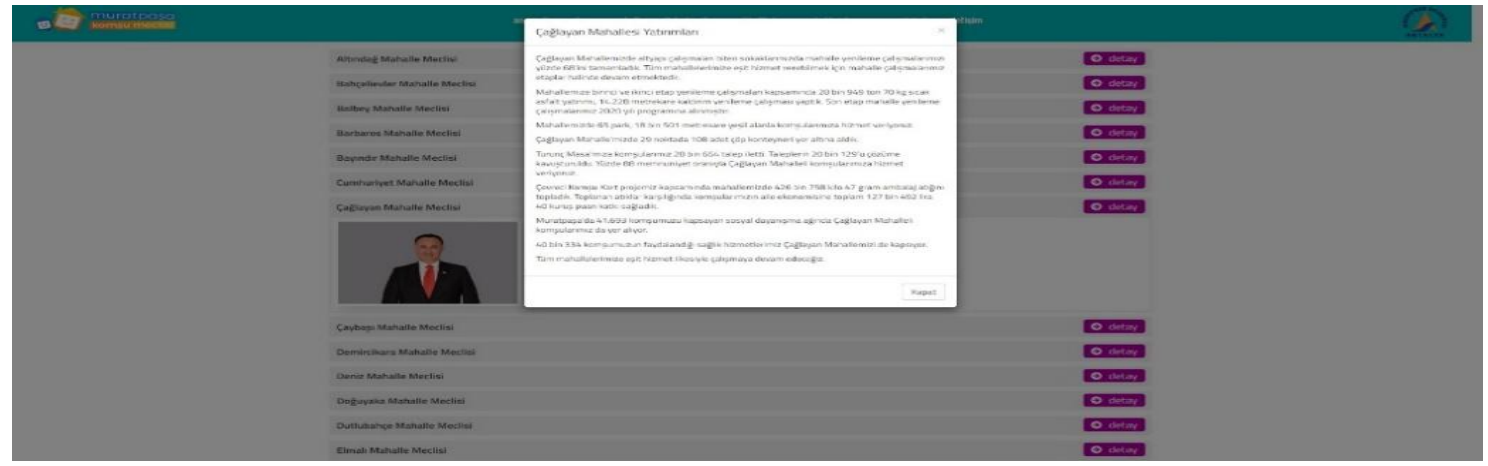

Kaynak: https://komsumeclisi.com/ (Erişim Tarihi: 05.03.2020).

- Forum: Bu sayfada oylama konusuna ilişkin bilgi veren bir metnin altında vatandaşların oylamaya ilişkin tüm görüş ve önerilerini tartışma ve ifade etme özgürlüğüne sahip olmaktadır.

Görüntü 4. Dijital Komşu Meclisi Uygulama Ekranı

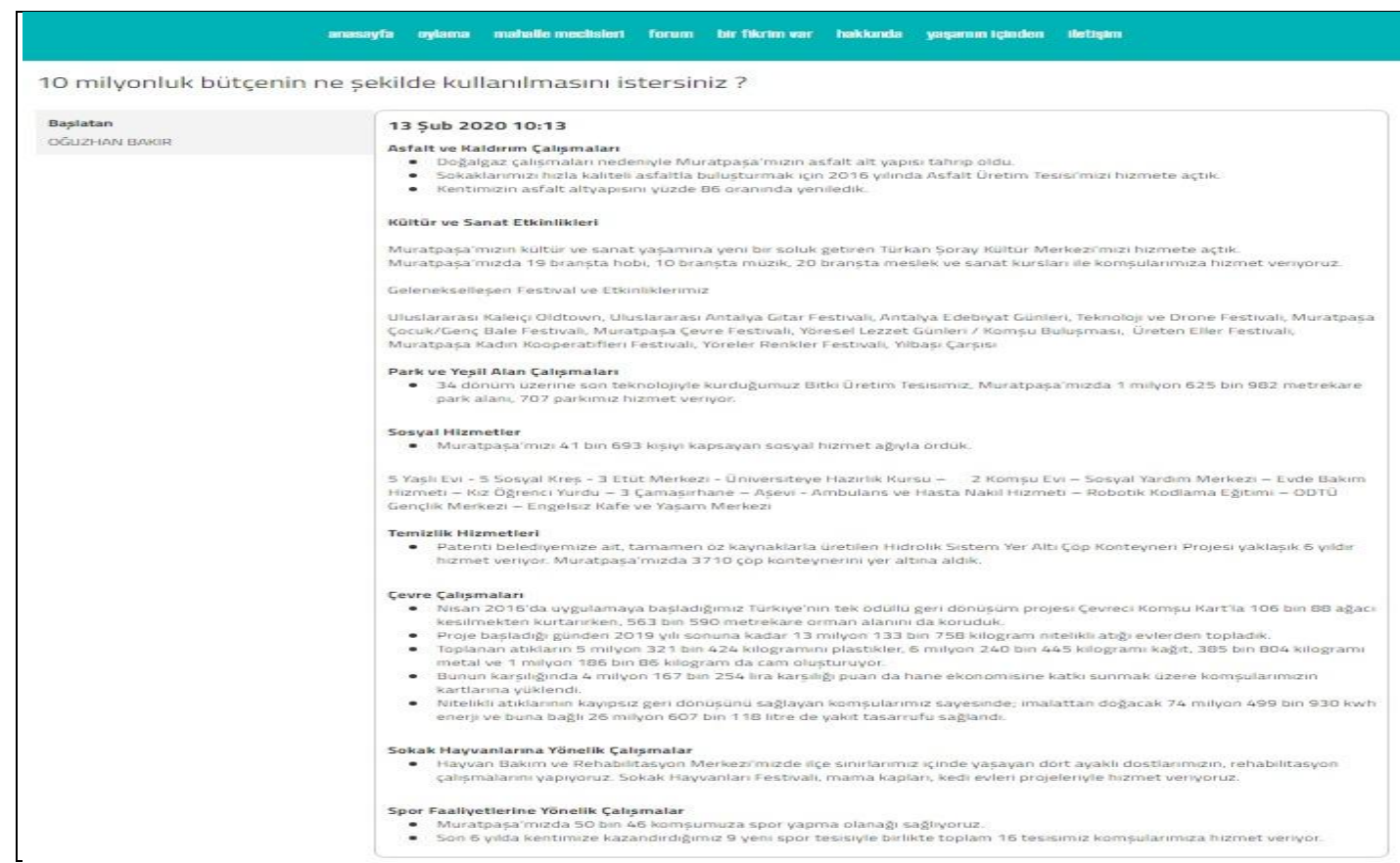

Kaynak: https://komsumeclisi.com/ (Erişim Tarihi: 05.03.2020).

Bir Fikrim Var: Bu sayfada kent sakinleri projelerini yaşama geçmek üzere Abdullah Sevimçok Sivil Toplum ve İnovasyon Merkezinin danışma kuruluna iletebilmektedir. Projenin uygulanabilirliği değerlendirilip, belediye encümenine gönderilmektedir. Belediye Encümeni'nin onayıyla proje hataya geçirilmektedir.

Görüntü 5. Dijital Komşu Meclisi Bir Fikrim Var Uygulaması Ekranı

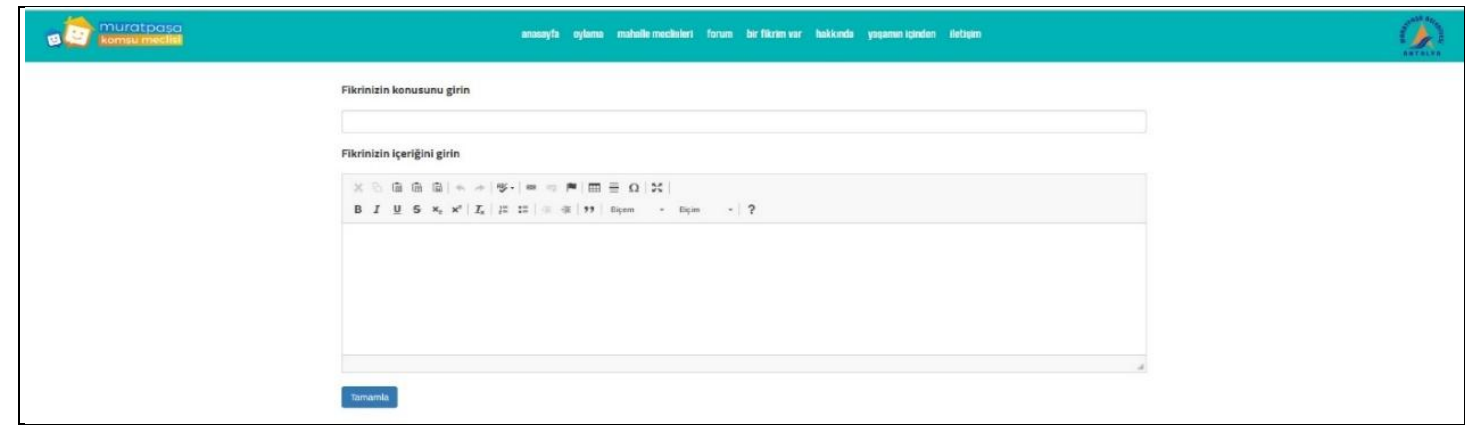

Kaynak: https://komsumeclisi.com/ (Erişim Tarihi: 05.03.2020). 
Bununla birlikte Komşu Meclisi uygulaması için bazı temel ilkeler de geliştirilmiştir. Bu ilkeler şunlardır:

- Komşu Meclisi'nde ilçe sınırlarında ikamet eden 13 yaş üstü herkes kent yönetimine doğrudan katkı sağlayabilmektedir.

- Muratpaşa'da resmi olarak ikamet eden herkes platformun doğal üyesidir.

- Tüm Muratpaşalılar eşit oy hakkına sahiptir.

- Komşu Meclisi’nde oylamaya sunulan konular en az 3 gün forumlarda tartışılmaktadır.

- Uygulamada yer alan komşu formunda tartış1lan konular veri analistleri tarafindan analiz edilerek belediyelerin yerel politikasına katkı sağlamaktadır.

- Üyelerin talebi doğrultusunda tartışma süresi oylamaya tabi tutularak uzatılabilmektedir.

- Oylanacak konu üç günün sonunda oylamaya açılmaktadır. Oylama süresi önceden duyurulmaktadır.

- Oylama sonuçları hukuki gereklilik halinde Muratpaşa Belediye Meclisi'ne, Komşu Meclisi'nin önerisi olarak sunulmaktadır.

- Komşu Meclisi'ne katılımcı bütçe yönetimini sağlamak için, her yıl belediye bütçesinin mali dengeleri gözetilerek bütçe aktarımı yapılmaktadır. Aktarılan bütçe miktarı 2020 yılı hariç her yılın Ağustos ayında duyurulmaktadır.

- Komşu Meclisi uygulaması dünya genelinde birçok ülkede uygulanan katılımcı bütçe uygulaması içinde örnek bir model teşkil etmektedir.

- Komşu Meclisi bütçesinin hangi hizmet alanlarında kullanılacağı Ağustos ayında oylamaya sunulmaktadır.

- Tüm komşular, "Bir Fikrim Var" bölümü üzerinden projelerini özgürce Abdullah Sevimçok Sivil Toplum ve İnovasyon Merkezi'ne (ASSIM) iletmektedir. ASSIM Danışma Kurulu'nun önerisi alınarak, Belediye Encümeni’nin onayıyla Komşu Meclisi'nde oylamaya sunulmaktadır.

- Komşu Meclisinde genel düzeyde ilçenin güncel ve geleceğe yönelik meseleleri, belediyenin sorumluluk alanına giren altyapı ve üstyapı yatırımları, vatandaşın günlük kent yaşamında karşılaştığı kent sorunları ve vatandaşların daha çok kendileriyle ilgili olan sorunlar ele alınmaktadır.

- Uygulama kapsamında ilk aktif oylama 2019 yılı içerisinde gerçekleştirilmiştir.

Dijital platforma kayıt olan Muratpaşalılar 8 ana başlıkta belirlenen hizmetler arasında, 10 milyon TL'lik belediye bütçesinin hangi hizmetler için kullanılmasını istediklerine dair oylamaya katılmışlardır. Oylama bir hafta sürmüştür. Uygulamanın internet sitesi www.komsumeclisi.com aç1lışında yer alan panelde, bütçenin kullanılacağı hizmet alanları yer almıştır. Komşu Meclisi'ne üye olan Muratpaşalı vatandaşlar, sokak hayvanlarına yönelik çalışmalardan asfalt ve kaldırıma kadar 8 başlık altında hizmetlerden ikisini seçerek hizmetin nereye ve nasıl yapılacağını oylamaktadır.

Tablo 2. Komşu Meclisinin 10 Milyon TL’lik Belediye Bütçesinin Hangi Hizmetler İçin Kullanılacağı

\begin{tabular}{|c|c|}
\hline Asfalt ve Kaldırım Çalışmaları & Kültür ve Sanat Etkinlikleri \\
\hline Temizlik Hizmetleri & Sokak Hayvanlarına Yönelik Çalışmalar \\
\hline Park ve Yeşil Alan Çalışmaları & Çevre ve Yenilenebilir Enerji Hizmetleri \\
\hline Spor Faaliyetleri & Sosyal Hizmet Çalışmaları \\
\hline
\end{tabular}

Kaynak: https://muratpasa-bld.gov.tr

Komşu Meclisi'yle Muratpaşa'da hayata geçirilen iletişimi ve etkileşimi öngören katılımcı yönetim anlayışını geliştirerek bir demokrasi kültürü haline getirmek hedeflenmektedir. Komşu Meclisi ile katılımcı demokrasi anlayış1; görülebilir, ölçülebilir ve raporlanabilir hale getirerek derinleştirilmek istenmektedir. Uygulama ile Muratpaşa' da ortak iyiliği, kent bilincini, komşu duyarlılı̆̆ını, biz dilini, geleceği birlikte kurgulama heyecanını yükseltmek, kentin ortak mutluluğunu arttırmak temel amaçtır. Yanı sıra mümkün olan en üst düzey dijital araç 
ve teknolojileri kullanarak, tüm komşuların eşit ve adil bir şekilde kent yönetimine katılımını sağlamak, ortak karar alma kapasitesini arttırmaktır. Son derece hızlı yaşanan bu süreç, oy vermeyle sinırlı vatandaşlık pratiğini de etkilemektedir. Uygulama karar alma süreçlerine katılmak isteyen, tartışan, yaşadığı sokağa, mahalleye ve kente dair söz söyleyen, müşterekleri arayan ve kamusal iyiye ulaşmaya çalışan model bir aktif vatandaşl1k dönemi başlatmayı amaçlamaktadır.

\section{SONUÇ}

Yaşamın her alanında Endüstri 4.0'ın ürettiği değişimler hissedilmektedir. Bugün ve gelecek nesiller için yazılım ile yeni bir dil, yapay zeka ile yeni bir anlayış, robotlar ile öğrenen makinalar, dijital medya ile de yeni bir sosyal alan yaşanmaktadır. Muratpaşa Belediyesi tarafından uygulamaya konulan "Komşu Meclisi" uygulaması da bu anlamda sürdürülebilir ve doğrudan demokrasi anlayışının bir kültür haline gelmesini ve kuşaklara aktarımını yaşamın ayrılmaz bir parçası haline getirebilir şekilde tasarlanmıştır. $\mathrm{Bu}$ anlamda oy verme yaşının 13 yaş ve üstü olarak belirlenmesi, gençlerin ve çocukların etkin hizmet aldığı yerel yönetimlerle demokrasi deneyimine başlamaları projenin sürdürülebilirliğinin de bir göstergesidir.

Vatandaşların maksimum düzeyde kent yönetimine katılımını sağlayan Komşu Meclisi, kent yaşamına dair aidiyet duygusunu arttırmaya, demografik farklılıkları minimize ederek, yurttaşların ortak karar almalarını ve bir paydada buluşmasını sağlamaya, ortak yaşamın sorunlarını ve ihtiyaçlarını mahalle mahalle belirleme ve çözüme kavuşturmaya, mahalelerin ihtiyaçları doğrultusunda, eşit ve adil bir şekilde kamu hizmetinden faydalanmasını sağlamaya, komşuluğu ve bir arada barış ve huzur içinde yaşama deneyimini arttırmaya, kentin gündelik yaşamını, vatandaşların yaşamın gerçek ihtiyaçlarından yola çıkarak verdikleri kararlar doğrultusunda düzenlemeye ve kamu kurumunun ve yöneticilerinin vatandaş nezdinde güvenilirliğini pekiştirmeye çalışmaktadır. Bu uygulama vatandaşların; çevrimiçi olarak bir devlet kurumuyla doğrudan etkileşime geçebilmesini, kamu yöneticileri ve yetkilileri ile işbirliğinde bulunabilmesini, kent yaşamına yönelik kendi kararlarını alıp, uygulayabilmelerini ve yönetime doğrudan katılımlarını mümkün kılmaktadır. Ayrıca uygulama yönetimde; şeffaflığı, gerçek geri bildirimleri almayı, toplumun ortak konularına doğrudan eğilmeyi, maksimum düzeyde hesap verilebilirliği ve açık yönetimi de vurgulanmaktadır. Ancak uygulamaya girebilmek için kişinin ikametgahının Murtapaşa'da olması, katılımcılar için önemli kısıtlardan biridir. Bu durum Muratpaşa'da yaşayan ancak ikametleri Muratpaşa'da olmayan vatandaşların aktif katılımını engellemektedir. Diğer taraftan her ne kadar 13 yaşındaki çocukların oy verme hakkı olsada bu yaşın daha da düşürülmesi çocuklar arasında demokrasi bilincinin gelişmesine de olanak sağlayacaktır.

Son söz, kentsel siyaset kentsel demokrasiden soyutlanamaz. Kentin kimliğini, yaşam kalitesi göstergelerini ve geleceğini değiştiren bütün kararlar yasal denetimin dışında mutlaka sivil toplum ve kamuoyu ile alınmalıdır.

\section{KAYNAKÇA}

AKBULUT, Mahmut Umut Ferman ve GÖKÜŞ, Mehmet (2017), "Küreselleşme ve Yerelleşme Sürecinde Bölgesel Kalkınma Ajansları", Selçuk Üniversitesi Sosyal Bilimler Meslek Yüksekokulu Dergisi, S.20(1), ss.79-88.

AKDOĞAN, Yalçın (2009), "Yerel Siyaset", TASAM Siyasal İletişim Enstitüsü, http://www.siyasaliletisim.org/index.php/ariv/makale/342-yerel-siyaset.html, (Erişim Tarihi: 05.01.2020).

AKMAN, Elvettin (2019), Kamu Politikaları, Nobel Yayınları, Ankara.

AKMAN, Kaan (2017), “Türkiye’de Yerel Yönetimlerin Yerel Demokrasi Bă̆lamında Irrdelenmesi”, Süleyman Demirel Üniversitesi 1. Uluslararası, 6. Ulusal Yerel Yönetimler Öğrenci Kongresi, 18-20 Ekim 2017, Isparta.

ALKAN, Ayten (2000), Yerel Politika ve Kadın, Ankara Üniversitesi Kadın Sorunları Araştırma ve Uygulama Merkezi Yayını, Ankara.

ARSLAN, Onur Kahan (2016), Üniter, Federal ve Bölgesel Devletlerde Yerel Yönetim Esasları, Adalet Yayınları, Ankara.

AYKAÇ, Burhan (1999), “Türkiye'de Kamu Yönetiminin Küçültülmesi, Yerel Yönetimler ve Yerel Demokrasinin Amaçları”, Gazi Üniversitesi İktisadi ve İdari Bilimler Dergisi, S.1, ss.1-12. 
BARDHAN, Pranab ve MOOKHERJEE, Philip (2006), "The Rise of Local Governments: An Overview", Decantralization and Local Governance in Developing Countries (Ed. Pranab Bardhan ve Philip MookherjeE), MİT Pres.

BELlì, Aziz (2015), "Yerel Yönetimlerde Kadın Temsili ve Yerel Demokrasi”, Yasama Dergisi, S.31, ss.6588.

BULUT, Yakup ve YILMAZ, Vedat (2019), “Türkiye'de 6360 Sayll Yasa Sonrası İl Özel İdarelerinin Geleceğì", Türkiye Vizyonu Multidisipliner Çalışmalar (Ed. Bülent Kırmızı, Bahar İşigüzel), Ekin Yayınevi, Bursa, ss.731-746.

CHOİ, Jin-Wook, CHOE, Chang Soo ve KİM, Jaehoon (2013), Local Government and Public Administration in Korea, Local Government Officials Development Institute (LOGODI), Korea.

COŞKUN, Atilla (2016), Özerk Yerel Yönetim ve Katılımcı Demokrasi Yaklaşımıyla, Türkiye İçin Yeni Bir Anayasa Modeli, Legal Yayıncılık, İstanbul.

CRABTREE, John (2014), “Finding Local Government: Uses of Peru's CANON System”, Bulletin of Latin American Research, S.33(4), ss.452-467.

ÇELIKK, Vasfiye, ÇELIK, Fikret ve USTA, Sefa (2008), "Yerel Demokrasi ve Yerel Özerklik İlişkisi”, Niğde Üniversitesi İktisadi ve İdari Bilimler Fakültesi Dergisi, S.1(2), ss.87-104.

ÇETIN, Sunay (2010), "Kamusal Karar Alma Sürecinde E-Demokrasi Uygulamalarl ve Türkiye”, Yayınlanmamış Yüksek Lisans Tezi, Dokuz Eylül Üniversitesi Sosyal Bilimler Enstitüsü, İzmir.

ÇETINKAYA, Özhan ve KORLU, Kutlu Rükan (2012), "Yerel Demokrasinin Sağlanmasında Katılımcılık Süreci ve Kent Konseylerinin Rolü”, Maliye Dergisi, S.163, ss.95-117.

ÇİÇEK, Yeter (2014), “Geçmişten Günümüze Türkiye'de Yerel Yönetimler”, KSÜ Sosyal Bilimler Dergisi, S.11(1), ss.53-64.

DEMIR, Hakan ve KARAKÜTÜK, Mehmet (2003), "Yerel Yönetimler ve Hizmette Yerellik: Subsidiarite Ilkesi”, Bilgi Dergisi, S.7(2), ss.65-77.

DYE, R. Thomas (1987), Understanding Public Policy, Englewood Cliffs N.J. Prentice-Hall, New Jersey, SixthEdition.

ERDOĞAN, Oğuzhan (2019a). Cumhurbaşkanlığı Hükümet Sisteminde Yerel Yönetimler, Sage Yayınları, Ankara.

ERDOĞAN, Oğuzhan (2019b), "Yerel Yönetimlerde Katılımcı Mekanizmalar ve Trabzon Büyükşehir Belediyesi Örneği”, Bitlis Eren Üniversitesi İïBF Akademik İzdüşüm Dergisi, S.4(2), ss.295-310.

ERYILMAZ, Bilal (2013), Kamu Yönetimi, Umuttepe Yayınları, Kocaeli, 6. Bask1.

FALAY, Nihat, KESIK, Ahmet, ÇAK, Murat ve KARAKAŞ, Mehmet (2009), Türkiye'de Yerel Yönetimler, Seçkin Yayınları, Ankara.

GÖÇOĞLU, Volkan (2014), “Kamu Politikası ve Sosyal Medya İlişkisi”, Yayınlanmamış Yüksek Lisans Tezi, Hacettepe Üniversitesi Sosyal Bilimler Enstitüsü, Ankara.

GÜLER, Birgül Ayman (2009), Türkiye'nin Yönetimi-Yapısı, İmge Kitapevi, Ankara.

GÜLER, Tahsin ve ŞAHNAGIL, Sinem (2017), "Dijital Demokrasi ve Yönetişim İlişkisi Çerçevesinde EDemokrasi/E-Devlet Uygulamalari”, Journal of Emerging Economies and Policy, S.(2(2), ss.16-29.

HILL, M. Dilys (1974), Democratic Theory and Local Government, Routledge Ltd., London and New York.

HORDİJK, Michaela (2009), "Peru's Participatory Budgeting: Configurations of Power, Opportunities for Change”, The Open Urban Studies Journal, S.2, ss.43-55.

İPEK, Selçuk (2016), Türkiye'de Yerel Yönetimlerin Mali Yapısı, Ekin Yayınları, Bursa.

KABOĞLU, İbrahim (2000), Anayasa ve Toplum, İmge Yayınları, Ankara.

KARAARSLAN, Mehmet (2007), “Türkiye'de Yerel Yönetimler Reformu Bağlamında Yerel Yönetimlerin Özerkliği ve Denetim”, Yayınlanmamış Doktora Tezi, Ankara Üniversitesi Sosyal Bilimler Enstitüsü, Ankara. 
ERDOĞAN, Oğuzhan - Yerel Politikaların Şekillenmesinde Dijital Demokrasi Uygulaması: Antalya Muratpaşa Belediyesi Komşu Meclisi

KALABALIK, Halil (2005), Avrupa Birliği Ülkeleriyle Karşılaştırmalı Yerel Yönetimler Hukuku, Seçkin Yayıncilik, ANKARA.

KARAKILÇIK, Yusuf (2016), Yerel Yönetimler, Seçkin Yayıncılık, Ankara.

KAYPAK, Şafak, YILMAZ, Vedat ve BIMAY, Muzaffer (2017), “Dijital Çağda Yerel Yönetimler”, Süleyman Demirel Üniversitesi İỉBF Dergisi, S.22(Kayfor'15 Özel Sayıs1), ss.1798-1813.

KELEŞ, Ruşen (2012), Yerinden Yönetim ve Siyaset, Cem Yayınevi, İstanbul, Genişletilmiş 8. Basım.

KOÇ, Firdevs (2015), “Türkiye’de Yerel Yönetimlerde Yerel Özerklik ve İdari Vesayet”, Yayınlanmamış Yüksek Lisans Tezi, İnönü Üniversitesi Sosyal Bilimler Enstitüsü, Malatya.

KUŞCU, Batuhan (2018), "Yerel Yönetimler ve Gençlik Politikaları Bağlamında Kocaeli Büyükşehir Belediyesi Örneği”, Yayınlanmamış Yüksek Lisan Tezi, Marmara Üniversitesi Sosyal Bilimler Enstitüsü, İstanbul.

MECEK, Mehmet (2018), "Türkiye'de Illçe Kent Konseylerinin Belediye Web Sayfaları Üzerindeki Görünülürlü̈̆̈̈ ve Etkinliği", Kent Yönetiminde Yeni Yaklaşımlar ve Etkin Belediyecilik Uygulamaları (Ed. Mehmet MECEK, Bekir Parlak, Emin Atasoy), Nobel Akademik Yayınları, Ankara, ss.1547-1556.

MUNICIPAL RESEARCH \& SERVICES CENTER OF WASHINGTON (1999), Local Government PolicyMaking Process, http://mrsc.org/getmedia/e46223b6-f3ac-4afb-b7d9-b2362edf6890/Local-GovernmentPolicy-Making-Process.pdf.aspx?ext=.pdf (Erişim Tarihi: 14.02.2020).

MUTLU, Fahri (2015), "Yerel Yönetimlerde Katılımcı Demokrasi Anlayışı: Kâğıthane (İstanbul) İlçesi Örneği”, Akademik Sosyal Araştırmalar Dergisi, S.3(10), ss.473-486.

ÖKMEN, Mustafa ve PARLAK, Bekir (2010), Kuramdan Uygulamaya Yerel Yönetimler: İlkeler, Yaklaşımlar ve Mevzuat, Alfa Aktüel Yayınları, Bursa, 2. Baskı.

ÖZDEN, Kemal (2014), "Yerel Yönetimler ve Demokrasi”, Yerel Yönetimlerde Güncel Sorunlar ve Tartışmalar (Ed. Kemal Özden), Seçkin Yayıncılık, Ankara, 2. Baskı, ss.9-40.

ÖZEL, Mehmet (2013), “Özerk Yerel Yönetimlerin Oluşumunda Kentlerin Tarihsel İ̧slevi”, Süleyman Demirel Üniversitesi İktisadi ve İdari Bilimler Fakültesi Dergisi, S.18(2), ss.47-64.

ÖZTÜRK, Azim (1994), “Türkiye’de Halkın Yönelime Katılması”, Türk İdare Dergisi, S.66(405), ss.45-56.

PARLAK, Bekir (2006), “Avrupa Birliği Perspektifinden Merkezi Yönetim - Yerel Yönetim İlişkileri”, Avrupa Perspektifinde Yerel Yönetimler (Ed. Hüseyin Özgür, Bekir Parlak), Alfa-Aktüel Yayınları, İstanbul.

PIRENNE, Henri (2003), Ortaçağ Kentleri (Çev. Şadan Karadeniz), İletişim Yayınları, İstanbul.

PUSTU, Yusuf (2005), "Yerel Yönetimler ve Demokrasi”, Sayıştay Dergisi, S.57, ss.121-134.

SANAY, Fatih (2019), "Yerel yönetimlerde Katılım Mekanizmaları ve Alanya Yabancllar Meclisi Örneği", Yayınlanmamış Yüksek Lisans Tezi, Selçuk Üniversitesi Sosyal Bilimler Enstitüsü, Konya.

SOBACI, Mehmet Zahid ve KÖSEOĞLU, Özer (2016), Başkanlık Sistemlerinde Yerel Yönetimler, Seta Yayınları, İstanbul.

ULUSOY, Ahmet ve AKDEMIR, Tekin (2010), Mahalli İdareler, Seçkin Yayınevi, Ankara, 6. Baskı.

YALÇINDAĞ, Selçuk (1996), Belediyelerimiz ve Halkla İlişkiler, TODAİE Yayınları, Ankara.

YILMAZ, Hakan, EMIL, M. Ferhat ve KERIMMOĞLU, Baki (2012), Yerel Yönetimler Maliyesi, Mali Hizmetler Derneği Yayınları, Ankara.

5393 say1l Belediye Kanunu (13.07.2005 tarih ve 25874 sayılı Resmi Gazete).

https://muratpasa-bld.gov.tr/ (Erişim Tarihi: 05.03.2020).

www.komsumeclisi.com (Erişim Tarihi: 05.03.2020). 